УДК 159.9.072.5

doi: $10.15330 /$ ps.8.1.184-190

\author{
Ірина Кривенко (Горбаль) \\ Український католицький університет (м. Львів) \\ i.horbal@ucu.edu.ua
}

\title{
МЕТОДИ ДОСЛІДЖЕННЯ ЗМІСТУ СНОВИДІНЬ У ПСИХОЛОГІї
}

\begin{abstract}
У статті здійснено огляд сучасної методології дослідження змісту сновидінь. Окреслено два ключові підходи до вивчення феномену сновидінь - об'єктивний, щзо фіксує особливості активності мозку при появі сновидіння та вивчається у рамках психофізіології, та суб'єктивний, у якому зосереджується увага на основних темах, емоціях, подіях у сновидіннях, а джерелом інформації є самозвіти, малюнки. Проаналізовано сучасні методи аналізу змісту сновидінь у рамках суб'єктивного підходу - методи збору даних та власне аналізу змістового наповнення сновидінь. Окреслено чотири джерела отримання інформачії про зміст сновидінь - лабораторії сну, психотерапевтичні сесії, журнали сновидінь, групові дослідження, обтрунтовано їх переваги та недоліки. Доведено, щуо результати досліджень, отримані у лабораторії та в домашніх умовах, суттєво не відрізняються та є взаємозамінними. Проаналізовано труднощі з об'єктивністю отриманих даних про сновидіння у ході психотерапевтичних сесій. Розглянуто основні техніки вивчення змісту сновидінь при проведенні групових досліджень, зокрема, поширену у західних дослідженнях техніку найостаннішого сновидіння. Розкрито можливості використання вільних асоціацій, метафоричного трактування символів, пошуку повторюваних тем та кількісного обчислення елементів сновидіння як ефективних методів аналізу змісту снів. Описано можливості використання різних математико-статистичних шкал при роботі 3 даними про зміст сновидінь, позитивні та негативні сторони їх застосування. Як приклад ефективного надійного методу опрацюювання змісту сновидінь наведено систему декодування Hall-Van de Castle з нормативами для організаціі досліджень з ї використанням. У висновках розкрито перспективи використання окреслених методів для забезпечення потреб теорії та практики психології.
\end{abstract}

Ключові слова: сновидіння, сон, методи дослідження, журнал сновидінь, система декодування змісту сновидінь, повторювані теми, метафоричний зміст.

Вступ. Сон та сновидіння споконвіків були загадковими, незрозумілими для людства феноменами. У давнину про сон думали як про стан, близький до смерті, проте відмінний від неї за глибиною (на це вказують перші фізіологічні теорії сну, що пов'язували його зі змінами температури тіла, швидкості кровообігу), який відкриває доступ до надприродних та несвідомих феноменів. Інтерес до тематики сну зріс у час епідемії летаргічного енцефаліту в Європі наприкінці XIX ст.: із понад 4 тисяч публікацій за цією тематикою 98\% було написано в I пол. XX ст. [19]. Надалі інтенсивний розвиток природничих наук та прогрес психологічних теорій призвів до осмислення сну та сновидінь як психофізіологічних процесів, що мають визначені біологічні функції та психологічний зміст. Зокрема, відкриття Kleitman та Aserinski [2] фази швидкого сну обгрунтувало, що сон - не монофазний, а складний психічний процес, суб'єктивний зміст якого сновидіння - має не надприродний, потойбічний, але цілком обгрунтований фізіологічний зміст. Freud [14] додав до нього ще психологічний аспект, що виводиться з досвіду людини.

У наш час означена проблематика залишається популярною. Міжнародна асоціація дослідження сновидінь (IASD) щороку проводить у США великий науковий конгрес. У Лондоні існує цілий Інститут досліджень сновидінь (DRI). Міжнародний журнал досліджень сну та сновидінь (IJORD) виходить двічі на рік, презентуючи результати студій. На жаль, у вітчизняній психології ця тематика практично не розвивається, трактування сновидінь залишаються в основному змістом роботи практикуючих психотерапевтів, тоді як закономірності їх проявів, етнокультурні та індивідуальні особливості залишаються невивченими. Сновидіння як об'єкт наукових досліджень є складним та суперечливим феноменом, а методологія їх дослідження та розуміння змісту і функцій сновидінь досі викликає чимало суперечок.

Метою актуального теоретичного огляду $є$ визначення провідних напрямів сучасних досліджень сновидінь у психології та в суміжних галузях і окреслення можливостей аналізу змісту сновидінь для отримання інформації про особливості перебігу несвідомих процесів і забезпечення потреб психологічної практики. 
Підходи до вивчення сновидінь. На сьогодні дослідження сновидінь реалізуються у межах двох підходів. 3 одного боку, вивчають зміст сновидінь: теми, емоції, образи, події, що виникають, а основними методами при цьому є самозвіти, малюнки. Суттєвим недоліком при цьому є ефект Хотторна (звіти досліджуваних часто бувають перебільшеними, яскравішими за реальні образи, такими, щоб експериментатору було цікавіше). Водночас, цим методом отримано чимало даних про наявність спільної тематики снів незалежно від культурних особливостей та про зв'язок суб'єктивних образів із подіями життя людини [3].

Інший спосіб досліджень - вивчення активності мозку у час, коли виникло сновидіння. Найчастіше 3-поміж методів тут застосовуються ЕЕГ та функціональне МРТ, записи змін локального мозкового кровотоку та витрат кисню різними ділянками, реєстрація вегетативних функцій. Цікаво, що зміст сновидінь значною мірою корелює з тим, що відбувається з організмом на стадії швидкого сну: інтенсивність подій у сновидінні пов’язана з частотою серцевих скорочень, пульсом тощо. Погляд уві сні вліво і вгору відображається у динаміці рухів очей за тією ж траєкторією, активність рухових зон кори при спогляданні картин руху власного тіла уві сні співпадає з реальним рухом [6;28].

Отже, фактично, мова йде про два підходи - суб'єктивний, що цікавиться змістом несвідомих переживань, суб'єктивними картинами, які виникають під час сну на певних його стадіях, та об'єктивний, коли фіксуються фізіологічні зміни під час споглядання сновидіння. Зосередимо увагу на суб'єктивних методах, зокрема, на методах збору інформації про зміст сновидіння та психометрії сновидінь.

Вивчення змісту сновидінь. Систематичний аналіз контенту сновидінь дав змогу виділити чимало закономірностей, зокрема, вікових, гендерних, етнокультурних особливостей, специфіки наповнення та тривалості снів, їх залежності від періоду бадьорості тощо. Domhoff [8] зазначає, що це поклало початок окремому напрямку досліджень у цій сфері - психопатології змісту сновидінь $[12 ; 13 ; 31]$.

Дослідник змісту сновидінь стикається з низкою труднощів. По-перше, не всі сновидіння запам'ятовуються, а, отже, втрачається значна частина емпіричного матеріалу. 3 психофізіології відомо, що сон триває на двох якісно відмінних етапах - повільному та швидкому, відмінності між якими пов'язані 3 різними анатомо-фізіологічними механізмами, що їх забезпечують. Після відкриття фази парадоксального сну певний час вважалося, що сновидіння виникають саме на цьому останньому етапі циклу, втім численні подальші дослідження $[1 ; 5 ; 29]$ вказують на те, що досліджувані звітують про наявність суб'єктивних картин також після прокидання із дельта-сну, хоча це відбувається значно рідше. Відтак, міра запам'ятовування сновидінь різна залежно від фази прокидання: у швидкому сні сновидіння запам'ятовуються частіше [22], можливо, тому, що тривалість повільного сну до ранку зменшується на користь швидкого. Проте цей аргумент також неоднозначний: Herman 3 колегами [17] пропонували досліджуваним однієї з груп «засіб для покращення запам'ятовування сновидінь». Під дією плацебо вони справді краще запам'ятовували сни, аніж контрольна група.

По-друге, при організації досліджень, що беруть до уваги зміст сновидінь як матеріал для аналізу його психологічних особливостей, важливим питанням $є$ те, що саме повинно фіксуватися серія сновидінь однієї людини чи у певний момент пригадані сни групи досліджуваних. Відтак, виникає також організаційне питання, як саме повинен збиратися такий емпіричний матеріал. Domhoff розглядає чотири джерела звітів про сновидіння: ті, що отримані у так званих лабораторіях сну; на сесіях психотерапії; занотовані в особистих журналах сновидінь; записані у спеціальних бланках при проведенні групових досліджень [8]. Цікаво, що до уваги при цьому не беруться опитувальники, які містять питання про те, як людина думає, чи їй сняться ті чи інші речі, бо таке формулювання передбачає вивчення особистісного стилю чи культурних переконань, що стосуються сновидінь, а не їх змісту як такого. Більше того, порівняння результатів таких опитувань та досліджень з використанням відкритих описів сновидінь у двох співмірних групах 
вказують на розбіжність результатів: наприклад, в опитувальниках значно рідше згадуються епізоди появи у сновидіннях агресії, аніж у вільних описах [16].

Перевага збору матеріалу в лабораторії сну полягає у можливості спостереження за сном людини у контрольованих умовах. Зокрема, можливо контролювати момент прокидання, здійснювати його у швидкому чи наприкінці глибокої стадії повільного сну, максимізуючи можливість пригадати сновидіння, та отримати таким чином 4-5 наративів за ніч. Власне, таким способом була доведена хибність думки про те, що існують люди, яким ніколи нічого не сниться, 3'ясувалося, що це пов'язано лише з особливостями їхньої пам'яті та моментом прокидання [4].

Одне із питань, що на сьогодні дуже дискутується в літературі, та яке намагаються вирішити дослідники лабораторним методом, - чи існує відмінність у змісті сновидінь залежно від того, на якій стадії вони виникли. Частина дослідників виявила відмінності сновидінь: наприклад, у глибокому сні вони не настільки яскраві, більш раціональні та реалістичні, відповідають змісту мислення у стані бадьорості, аніж у парадоксальному, коли з'являються фантастичні кольорові образи [18]; соціальні контакти, пов'язані з агресією, частіше сняться у швидкому, а 3 дружбою - у повільному сні [21]. Це можна пояснити активізацією лімбічної системи при переході до швидкого сну. Такі результати також наштовхують дослідників на роздуми про функціональне значення сновидінь. Ruby [25] трактує сновидіння як спробу мозку вирішити проблему на символічному рівні: на основі даних ЕЕГ встановлено, що стадія швидкого сну виглядає як чергування альфаритмів, які у стані бадьорості виникають за умови задоволеності актуальних потреб, і тета-ритмів, що спостерігаються у період сильного напруження, переживання стресу. В теорії пошукової активності Ротенберга-Аршавського дослідники припускають, що у швидкому сні відбувається компенсація стану відмови від пошуку вирішення певної проблеми у період бадьорості. Так, у людей із депресивними та тривожними розладами швидкий сон після засинання наступає не через 70-100 хвилин, як у нормі, а уже через 40; у тварин після пасивно-захисної поведінки REM-сон стає тривалішим, а після бійки в природних умовах - навпаки, скорочується [24]. Сновидіння, відтак, трактується як форма переживання нерозв'язаного конфлікту.

Водночас, в інших дослідженнях (наприклад, Strauch та Meier [27]) не встановлено відчутних відмінностей змісту сновидінь залежно від стадії прокидання, i Domhoff навіть робить категоричний висновок про те, що хоч психологічний зміст у сновидінь $\epsilon$, адаптивно вони беззмістовні [9].

Дослідники задавалися питанням, чи штучність лабораторних умов суттєво позначається на звітах про сновидіння, однак довели, що особливих відмінностей порівняно із тими, хто спав удома, не виявлено [10]. Сдині статистично значущі відмінності було встановлено щодо звітування про появу актів фізичної агресії, що очікувано частіше згадували ті, хто проходив дослідження у домашніх умовах.

Відтак, єдиною трудністю проведення лабораторних досліджень сновидінь $є$ їх часова затратність та висока вартість.

Простішим у цьому сенсі є отримання інформації про сновидіння в ході психотерапії. Ба більше, такі звіти доповнюються багатим біографічним матеріалом та фантазіями. Попри це, не всі терапевти працюють зі снами, ще менша кількість веде записи про таку роботу. Крім того, клієнтів психотерапевтів навряд чи доцільно розглядати як репрезентативну вибірку, тим більше, що вони доволі нечисленні. Недивно, що зібрані таким чином описи сновидінь нечасто є об'єктом наукового аналізу, вони використовуються в основному для індивідуального чи внутрішньогрупового аналізу.

Третє джерело інформації про зміст сновидінь широко використовують юнгіанські аналітики - це журнали сновидінь. Однак, не менш ефективне для психологічних досліджень використання таких «щоденників», що їх людина веде з особистих, творчих, інтелектуальних причин [8]. У випадку ведення журналу сновидінь за межами терапевтичного сетінгу записи можуть бути навіть більш інформативними, оскільки сновидіння у них записуються без чіткої мети бути проаналізованими, a, отже, менш імовірно приховуватимуться чи піддаватимуться 
«ментальній цензурі» з різних причин, наприклад, через опір у психотерапії (на це, зокрема, вказують Webb з колегами [30], називаючи такі дослідницькі заміри «нереактивними»).

Недоліками даного методу дослідження з погляду науки, звичайно, є обмежена можливість аналізувати такі записи - навіть ведучи своєрідні «щоденники» сновидінь, не всі люди погодяться стати досліджуваними і віддати особисті записи на аналіз. Крім того, записи можуть бути нерегулярними та вибірковими, не даючи цілісної картини. Тому Domhoff рекомендує цей метод радше як додатковий при дослідженні сновидінь [8].

3 точки зору методології наукових досліджень найбільш об'єктивним, структурованим та ефективним для отримання великого масиву даних про сновидіння $\epsilon$ класичне групове дослідження. У такій формі найпростіше зберегти анонімність учасників дослідження, хоча при цьому втрачається чимало особистісного матеріалу.

Класично подібні дослідження проводяться у формі запитання про те, який останній власний сон може пригадати людина («пригадайте останній власний сон, неважливо, коли Ви його бачили - минулої ночі, минулого тижня чи минулого місяця») [7]. На звіт у довільній формі виділяється 15-20 хвилин, він пишеться у приміщенні, де проводиться групове дослідження. У ньому просять також вказати дату (хоча б приблизну), коли виникло сновидіння. Така техніка носить назву «техніки найостаннішого сновидіння» (The Most Recent Dream technique, за Domhoff [8]), і для подальшого аналізу отриманих даних використовується спеціальна система декодування отриманих даних, запропонована Hall та Van de Castle [15].

Виходячи із зазначеного вище, можна констатувати, що, попри ефемерність феномену сновидінь, організація їх досліджень у психології є доволі типовою, як і інших психічних явищ. Запропоновані методи збору матеріалу відкривають можливості для нових досліджень, зокрема, і в нашій державі, не потребуючи особливих ресурсів та особистих надзусиль.

Методи аналізу контенту сновидінь. Серед поширених у літературі методів аналізу змісту сновидінь можна виділити вільні асоціації про сон, пошук метафоричного сенсу сновидіння, вивчення повторюваних тем (якісні методи аналізу) та кількісний аналіз елементів сновидіння [8]. Для контролю ефекту Пігмаліона дослідник не повинен багато знати про аналізанта, щоб уникати трактування сновидінь на основі власних очікувань. Водночас на основі такого «сліпого аналізу» сновидінь $€$ можна висувати гіпотези про те, які думки та дії здійснює досліджуваний у період бадьорості.

Метод вільних асоціацій, запропонований Freud [14], є теоретично нейтральним та може застосовуватися не лише в межах психоаналізу; він передбачає висловлення сновидцем всього, що приходить на думку та стосується кожного елементу сновидіння. Це дає змогу прив'язати зміст сновидіння до щоденних життєвих подій, які мають емоційний резонанс. Водночас вільні асоціації зазначай значно виходять за межі сновидіння, ускладнюючи аналіз цього окремого психічного явища. I хоча у працях, що стосуються аналізу сновидінь, такий метод застосовувався (наприклад, [11]), доповнення звітів про сновидіння вільними асоціаціями виявилося не більш інформативним, аніж самі звіти [23].

У психотерапевтичному сетінгу вільні асоціації трактуються на символічному рівні 3 урахуванням їхнього метафоричного змісту. Таким же чином у частині наукових досліджень проводиться аналіз описаних у журналах сновидінь, де основою символів сновидінь вважається велика система універсальних концептуальних метафор Західної цивілізації [20]. Однак, аналіз сновидінь у такій формі має низку труднощів, зокрема, не існує чітких доказів щодо того, скільки та які саме сни мають власне символічний зміст, яку саме метафоричність - загальнолюдську чи особисту, базовану на власному досвіді, несуть у собі сновидіння (останню проблему пробують вирішувати вивченням повторюваних елементів у серіях сновидінь, шукаючи концептуальну метафору для них). Загалом, систематичного наукового підходу для використання цього методу на сьогодні немає.

Тематичний аналіз сновидінь $\epsilon$ продовженням метафоричного аналізу. При використанні цього методу до уваги беруться повторювані теми у серіях сновидінь однієї людини, або у снах 
різних людей з однієї групи. Однак варіант групового аналізу здійснити значно складніше та й результати його неоднозначні, a, отже, віднайти закономірності, генералізувати дані 3 використанням цього методу непросто. Domhoff називає такий аналіз лише загальним, непридатним для детального аналізу змісту сновидінь [8].

Усі зазначені недоліки якісних методів аналізу змісту сновидінь призвели до розробки методів кількісного аналізу - «контент-аналізу» [8]. Його основне завдання - створення можливостей для верифікації результатів досліджень різними дослідниками у різних вибірках.

Дослідники задалися питанням, у яких одиницях повинні бути здійснені вимірювання при аналізі змісту сновидінь. У різних дослідженнях використовувалися усі типи шкал: ієрархічні порядкові (у більшості), інтервальні чи абсолютні (наприклад, при оцінюванні міри емоційності чи дивності сновидіння), та номінативні (фіксуючи наявність тих чи інших елементів уві сні, наприклад, чи були присутні люди у сновидінні, чи ні). Яскравим прикладом ефективного застосування ієрархічних шкал при вивченні змісту сновидінь $є$ лонгітюдне дослідження Foulkes [12], завдяки якому продемонстрована динаміка дитячих сновидінь, від простих, статичних образів без присутності сновидця у віці до 6 років, до розгорнутих історій, у яких сновидець бере активну участь, до 8-річного віку. Загалом, рангові шкали корисні при оцінюванні елементів сновидінь за їх інтенсивністю (мірою активності, емоційності), без уваги до їх специфічного контенту. Типовими мінусами використання таких шкал є відомі недоліки ієрархічних шкал загалом - неоднозначність мір оцінок, їхня суб'єктивність, відсутність єдиного способу оцінювання образів, що виникають у сновидіннях (наприклад, у системі декодування снів Hall та Van de Castle [15] 1 бал присвоюється за появу у сновидінні агресивного висловлювання, 4 бали - за вбивство, але в сумі чотири агресивні фрази прирівнюються у кількісному сенсі до вбивства, що вочевидь у реальному житті не одне і те ж).

Таких недоліків позбавлені номінативні шкали (кожен вид агресії уві сні, наприклад, може бути внесений при опитуванні в окрему категорію видів агресії), повнота збору інформації у такій формі залежить лише від урахування великої кількості критеріїв, за якими оцінюють сновидіння, що часто робить такі опитування більш громіздкими, а на їхнє опрацювання йде більше часу. Ба більше, знайдені елементи у сновидіннях часто можуть не мати психологічного змісту.

У цілому, емпіричні шкали для дослідження змісту сновидінь включають у себе різні типи статистичних шкал, що оцінюють як рівні незвичності, незвичайності сну, так і наявність персонажів, домінуючі емоції, дії та взаємодії в образах сновидінь. Серед усіх систем кількісного опрацювання змісту сновидінь найбільшого поширення набула система декодування Hall та Van de Castle [15]. У ній є 10 базових категорій (герої; соціальні взаємодії; дії; удачі і невдачі; успіхи та поразки; емоції; обставини та об'єкти; описові елементи; елементи з минулого; їжа), а також оцінки міри інтенсивності розгортання дій та незвичних елементів. Система відзначається високою надійністю, дані для стандартизації отримано від респондентів з Канади, Свропи, Індії та Японії, розроблено норми для молоді різної статі та для літніх людей. Для ефективного використання системи необхідно зібрати 100-125 звітів про останні сновидіння [26].

Висновки. Отже, попри неоднозначність та химерність сновидінь як об’єктів психологічних досліджень вони є продуктом психічної реальності, а, отже, можуть бути цінними для розуміння особливостей людської психіки. Domhoff зазначає, що кількість чоловічих та жіночих персонажів, міра невезіння та фортуни, частіші агресивні, аніж дружні прояви, домінування негативних емоцій над позитивними $є$ типовими закономірностями змісту сновидінь у людей з усього світу [8]. Водночас існують суттєві індивідуальні відмінності цих явищ. Сучасна психологія шукає способи, як максимально об'єктивізувати результати таких досліджень, і з використанням зазначених вище технік аналіз змісту сновидінь може значною мірою збагатити отримані під час самооцінкових опитувань уявлення про особистість, отримуючи матеріал безпосередньо з несвідомого, а, отже, позбуваючись можливих упереджень та страхів перед саморозкриттям. Хоча в Україні цей напрям досліджень практично не представлений у літературі, він заслуговує на увагу та має суттєвий теоретичний і прикладний зміст: з одного боку, розкриває можливості розуміння несвідомих 
психічних явищ та їхніх етнокультурних особливостей, з іншого, може широко використовуватися у психологічному консультуванні та психотерапії як при роботі з особистісним розвитком, так і в контексті подолання проблем, пов'язаних зі сном.

1. Antrobus, J. (1983). REM and NREM sleep reports: comparison of word frequencies by cognitive classes. Psychophysiology, 20, 562-568.

2. Aserinsky, E., Kleitman, N. (1953). Regularly Occurring Periods of Eye Motility, and Concomitant Phenomena, During Sleep. Science, 118, (3062), 273-274.

3. Breus, M. (2015). How Do Scientists Study Dreams? Psychology Today [Electronic source]. Retrieved from: https://www.psychologytoday.com/.

4. Butler, S., Watson, R. (1985). Individual differences in memory for dreams: The role of cognitive skills. Percept Mot Skills, 53, 841-864.

5. Cavallero, C., Foulkes, D., Hollifield, M., Rebecca, T. (1990). Memory sources of REM and NREM dreams. Sleep, $13,449-455$.

6. Dresler, M., Koch, S., Wehrle, R., Spoormaker, V. I., Holsboer, F., Steiger, A., Sämann, P. G., Obrig, H. \& Czisch, M. (2011). Dreamed movement elicits activation in the sensorimotor cortex. Current Biology, 21 (21), 1833-1837.

7. Domhoff, G. (1996). Finding meaning in dreams: A quantitative approach. New York: Plenum Publishing Co.

8. Domhoff, G. (2000). Methods and measures for the study of dream content. In M. Kryger, T. Roth, \& W. Dement (Eds.), Principles and Practies of Sleep Medicine, 3 (pp. 463-471).

9. Domhoff, G. (2015). Dreaming as embodied simulation: A widower's dreams of his deceased wife. Dreaming, 25, 232-256.

10. Domhoff, G., Schneider, A. (1999). Much ado about very little: the small effect sizes when home and laboratory collected dreams are compared. Dreaming, 9, 139-151.

11. Foulkes, D. (1978). A grammar of dreams. New York: Basic Books.

12. Foulkes, D. (1982). Children's dreams. New York: Wiley.

13. Foulkes, D. (1985). Dreaming: A cognitive-psychological analysis. Hillsdale, NJ: Lawrence Erlbaum.

14. Freud, S. (1900). Die Traumdeutung. Retrieved from http://www.amazon.de/.

15. Hall, C., Van de Castle, R. (1966). The content analysis of dreams. New York: Appleton-Century-Crofts.

16. Hall, C., Domhoff G., Blick K., Weesner, K. (1982). The dreams of college men and women in 1950 and 1980: a comparison of dream contents and sex differences. Sleep, 5, 188-194.

17. Herman, J., Ellman, S., Roffwarg, H. (1978). The problem of NREM dream recall reexamined. In A. Arkin, J. Antrobus, \& S. Ellman (Eds.), The mind in sleep: Psychology and psychophysiology (pp. 59-62). Mahwah, NJ : Erlbaum.

18. Hobson, J., Stickgold, S., Pace-Shott, E. (1998). The neuropsychology of REM sleep dreaming. Neuroreport, 9, R1R14.

19. Kleitman, N. (1963). Sleep and wakefulness (2nd ed.). Chicago: University of Chicago Press.

20. Lakoff, G., Johnson, M. (1980). Metaphors we live by. Chicago: University of Chicago Press

21. McNamara, P., McLaren, D., Smith, D., Brown, A., Stickgold, R. (2005). A “Jekyll and Hyde” Within : Aggressive Versus Friendly Interactions in REM and Non-REM Dreams Psychological Science, 16 (2), 130-136.

22. Nielsen, T., Kuiken, D., Hoffmann, R., Moffitt, A. (2001). REM and NREM Sleep Mentation Differences: A Question of Story Structure? Sleep and Hypnosis, 3 (1), 9-17.

23. Popp, G., Luborsky, L., Crits-Cristoph, P. (1992). The parallel of the CCRT from therapy narratives with the CCRT from dreams. In L. Luborsky, P. Crits-Christoph (Eds.), Understanding transference (pp. 158-172). New York: Basic Books. RON

24. Rotenberg, V. (2001). Snovidyeniya, gipnoz i deyatyel'nost' mozga [Dreams, hypnosis and brain activity]. Moscow:

25. Ruby, P. (2011). Experimental Research on Dreaming: State of the Art and Neuropsychoanalytic Perspectives. Front Psychol., 2. Retrieved from https://www.ncbi.nlm.nih.gov/.

26. Schneider, A., Domhoff G. (1997). The quantitative study of dreams. Retrieved from http://www.dreamresearch.net/.

27. Strauch, I., Meier, B. (1996). In search of dreams: Results of experimental dream research. Albany: State University of New York Press.

28. Valli, K., Frauscher, B., Peltomaa, T., Gschliesser, V., Revonsuo, A., Högl, B. (2015). Dreaming furiously? A sleep laboratory study on the dream content of people with Parkinson's disease and with or without rapid eye movement sleep behavior disorder. Sleep medicine, 16 (3), 419-427.

29. Vyazovskiy, V., Delogu, A. (2014). NREM and REM Sleep: Complementary Roles in Recovery after Wakefulness. The Neuroscientist, 20(3), 203-219.

30. Webb, E., Campbell, D., Schwartz, R., Sechrest, L., Grove, J. (1981). Nonreactive measures in the social sciences. Chicago: Rand McNally.

31. Winget, C, Kramer M. (1979). Dimensions of dreams. Gainesville, FL.: University of Florida Press. 


\section{Iryna Kryvenko (Horbal) \\ METHODS FOR THE STUDY OF DREAM CONTENT IN PSYCHOLOGY}

The article reviews modern methodology of dream content studies. Two key approaches for studying of dream phenomenon are outlined, objective, which fixes the peculiarities of brain activity while dream occurs and is used in the field of psychophysiology, and subjective which is focused on main themes, emotions, and events in the dream, and the information sources are self-reports, pictures. Modern methods for analysis of dream content within the framework of subjective approach are analyzed, such as methods of collecting data and actually methods of analysis of content filling of dreams. Four sources of getting information on dream content are outlined - dream laboratory studies, psychotherapeutic sessions, dream journals and group studies; pluses and minuses of each method are substantiated. It is proved that the results of studies received in dream laboratories and in common conditions at home do not differ essentially and are permutable. The difficulties connected to the objectivity of received data on dreams during psychotherapeutic sessions are analyzed. The main techniques of studying dream content in form of group research are overviewed, particularly The Most Recent Dream technique which is widely spread in Western studies. The possibilities for using free associations, metaphoric interpretation of symbols, search of repeated themes, and quantitate evaluation of dream elements, as effective methods for analysis of dream content are depicted. The opportunities of using different statistical scales while working with data on dream content are described, together with evaluating their positive and negative sides. As an example of effective reliable method of studying dream content Hall-Van de Castle decoding system is exemplified, together with the research organizational norms for using it. For the conclusions, the perspectives of using these described methods for reaching theoretical and applied psychological goals are overviewed.

Keywords: dream, sleep, research methods, dream journals, decoding dream content system, repeated themes, metaphorical content. 